\title{
SURFACE OZONE CONCENTRATIONS AND THE METEOROLOGICAL CONDITIONS AT AN URBAN TROPICAL SITE IN THE SOUTHERN HEMISPHERE
}

\author{
Abel Antônio Silva
}

\begin{abstract}
Surface ozone plays a key role in the photochemistry of the low troposphere being associated with health and environmental problems. It is formed from a pool of reactions involving natural and anthropogenic pollutants, solar radiation, and the meteorological condition. In this study, 12-months of recent measurements of surface ozone concentration (SOC) are presented for an urban tropical site $\left(19.92^{\circ} \mathrm{S}, 43.94^{\circ} \mathrm{W}, 858 \mathrm{~m}\right.$ asl, $\left.331 \mathrm{~km}^{2}\right)$ in Brazil. An analysis of the SOC dependence on the meteorological conditions (cloud cover, wind direction and speed, number of rainy days, precipitation, humidity, and daily maximum temperature) is introduced. The daily maxima of the one-hour averaged data of SOC (1-h SOC) ranged from 8.7 to 96.1 parts-per-billion by volume (ppbv) and averaged $38.1 \pm 13.7 \mathrm{ppbv}$ ( $1 \sigma$ ), while the maxima of the monthly averages of the 1-h SOC varied from $24.5 \pm 8.8 \mathrm{ppbv}$ in early fall to $46.7 \pm 9.3 \mathrm{ppbv}$ in late winter. Monthly averages of $1-\mathrm{h}$ SOC and humidity showed fair linearity among the meteorological parameters investigated. In addition, the cloud cover in summer seems to affect SOC the most.
\end{abstract}

Keywords: ozone, clouds, meteorology.

RESUMO. 0 ozônio de superfície desempenha um importante papel na fotoquímica da baixa troposfera, estando associado a questões ambientais e de saúde. Ele é formado a partir de um grupo de reações envolvendo fontes naturais e antropogênicas de poluentes, radiação solar e condições meteorológicas. Neste trabalho, 12 meses de medidas recentes da concentração de ozônio de superfície (COS) são apresentadas para uma localidade urbana tropical (19,92 $\mathrm{S}, 43,94^{\circ} 0,858 \mathrm{~m}$ anm, $331 \mathrm{~km}^{2}$ ) no Brasil. Uma análise da dependência da COS com as condições meteorológicas (cobertura de nuvens, direção e velocidade dos ventos, número de dias chuvosos, precipitação, umidade e temperatura máxima diária) é introduzida. As máximas diárias da média horária de COS (1-h COS) variaram de 8,7 a 96,1 partes por bilhão em volume (ppbv) com média de 38,1 $\pm 13,7$ ppbv ( $1 \sigma$ ), enquanto as máximas das médias mensais de 1-h COS variaram de 24,5 \pm 8,8 ppbv no início do outono a 46,7 \pm 9,3 ppbv no final da primavera. As médias mensais de 1-h COS e umidade apresentaram uma linearidade razoável dentre os parâmetros meteorológicos investigados. Além disso, a cobertura de nuvens no verão parece ter afetado de forma mais intensa a COS.

Palavras-chave: ozônio, nuvens, meteorologia. 


\section{INTRODUCTION}

Apparently, the recovery of the ozone layer is in progress since the mid 1990's as a result of the Montreal Protocol ban on ozone depleting substances. The reduction in the year-round stratospheric ozone produced by ozone depleting substances over Brazilian latitudes was generally below $2.0 \%$ /decade, which generally represents a non-statistically significant value (Silva, 2007). On the other hand, the needs of the human society for economic growth push the use of technologies that increase pollution, especially surface ozone. This is one of the key issues concerning pollution for the coming decades according to the Intergovernmental Panel on Climate Change (IPCC, 2007).

A natural catalytic cycle based on the nitrates produces ozone through the photolysis of N02 and destroys it in the reaction with NO. However, surface ozone also results from anthropogenic sources. Highs in surface ozone concentration (SOC) - or, alternatively, the ozone mixing ratio - come out in the presence of solar radiation $(\lambda<420 \mathrm{~nm})$ plus primary pollutants like the volatile organic compounds (VOCs) from natural and anthropogenic sources and carbon monoxide $(\mathrm{CO})$ and the nitrates from power plants based on fossil fuel and car exhausts (Atkinson, 2000). Meteorological and geophysical parameters like temperature, relative humidity (or just humidity), cloud cover, precipitation, winds, aerosols, and plumes of smoke also play important roles in the determination of SOC (Kim \& Newchurch, 1998; Camalier et al., 2007; Duncan et al., 2008; Flynn et al., 2010). Surface ozone is a toxic and powerful oxidant leading to deleterious effects on materials and life (Tilton, 1989; Lippmann, 1991; McConnell et al., 2002; Bell et al., 2004; Pandrangi \& Morrison, 2008). The limits for human exposure to SOC vary worldwide depending on the local legislation (Meleux et al., 2007; Beig et al., 2008; Duncan et al., 2008; Shan et al., 2008), which are generally based on the World Health Organization recommendations (WHO, 1987). In Brazil, a resolution (No. 03 of June 28 of 1990, www.mma.gov.br/port/conama/res/res90/res0390.html) of the Conselho Nacional do Meio Ambiente (CONAMA) states an hourly averaged limit of $160 \mu \mathrm{g} \mathrm{m}^{-3}$ that must not be exceeded more than once a year. This limit is equivalent to 90 parts-perbillion by volume (ppbv) if temperature and atmospheric pressure are $23^{\circ} \mathrm{C}$ and $913 \mathrm{hPa}$ respectively.

Since SOC depends on many environmental parameters with seasonal dependence, some seasonality is expected to be found in the SOC measurements. The solar elevation and temperature affect the photolysis efficiency and chemical reaction speed, respectively, in the complex atmospheric mechanism of surface ozone production. Moreover, clouds and aerosols produce varia- tions in the incidence of solar radiation affecting SOC. Precipitation is the largest significant cause of reduction in $\mathrm{SOC}$ because it washes the pollutants out of the atmosphere in addition to reducing the incidence of solar radiation. The typical amounts of SOC for a site depend on local factors like weather, climate, geography, and economy robustness. In addition, air transportation of pollutants from distant places also represents an important source of SOC and SOC formation (Kim \& Newchurch, 1998; Duncan et al. 2008). Pristine sites or sites far from large urban polluted areas have shown maximum average SOC around 35 ppbv in Antarctica (Legrand et al., 2009), 70 ppbv in wild life parks like Yosemite National Park (Burley \& Ray, 2007), 80 ppbv in the Crete Island (Kouvarakis et al., 2000), or ranging from 15 to 70 ppbv in low polluted sites at mid and high latitudes (Oltmans et al., 1998). On the other hand, in metropolitan areas the maxima of average SOC generally peak over 90 ppbv several times a year (Mazzeo et al., 2005; Civerolo et al., 2007; Meleux et al., 2007; Beig et al., 2008; Shan et al., 2008; Velasco et al., 2008).

Series of SOC measurements worldwide are generally from mid and high latitudes, especially from networks operating in the Northern Hemisphere. Only a few of them refer to the low latitudes of the Southern Hemisphere. Since an increasing SOC is foreseen for the coming decades (IPCC, 2007), there is a demand for improving and spreading field campaigns for SOC measurements. In this study, 12-months of recent SOC measurements are presented for a station in a metropolitan center of the southeastern region of Brazil. An analysis of the measurements in relation to the meteorological parameters of cloud cover, wind direction and speed, precipitation, humidity, and daily maximum temperature is provided.

\section{MATERIALS AND METHODS \\ Site description}

Belo Horizonte (BH, Brazil) is the center of the $3^{\text {rd }}$ largest Brazilian metropolitan area. Table 1 shows the geographical and demographic data for BH (IBGE, 2011). Commercial and industrial activities are predominant in the region, where the industry of mining and high technology represents the main activities. As a municipality, BH has a fleet over 1.2 million vehicles fueled with gasoline, ethanol, gasoline-ethanol mix, diesel, biodiesel, and natural gas. Despite its renewed fleet of electronic injection engines coupled with catalytic exhaust converters, BH faces a significant production of gases and particle matter launched into the atmosphere by the traffic of vehicles. In terms of environment, $\mathrm{BH}$ is in a hilly area settled between the Savanna (Cerrado, to the west and north) and the remains of the Atlantic forest (Mata Atlântica, to the 
Table 1 - Geographical and demographic aspects of Belo Horizonte (BH)

\begin{tabular}{|c|c|c|c|c|c|c|}
\hline City & $\begin{array}{c}\text { Lat. }\left(^{\circ}\right) \\
\mathrm{S}\end{array}$ & $\begin{array}{c}\text { Long. }\left(^{\circ}\right) \\
\mathrm{W}\end{array}$ & $\begin{array}{c}\text { Altitude } \\
(\mathrm{m} \text { asl })\end{array}$ & $\begin{array}{c}\text { Area } \\
\left(\mathrm{km}^{2}\right)\end{array}$ & $\begin{array}{c}\text { Inhabitants } \\
\text { (millions) }\end{array}$ & $\begin{array}{c}\text { Car fleet } \\
\text { (millions) }\end{array}$ \\
\hline $\mathrm{BH}$ & 19.92 & 43.94 & 858 & 331 & 2.4 & 1.2 \\
\hline
\end{tabular}

east and south) about $400 \mathrm{~km}$ away from the Atlantic Ocean in the southeastern region of Brazil. The site features a tropical climate of altitude. Smoke and aerosol plumes from events of biomass burning outside the site are blown into it during the dry period in May-September when humidity falls below $20 \%$. The rainy period is in the November-March period. Seasons can be split up into: December, January, and February for summer; March, April, and May for fall; June, July, and August for winter; and September, October, and November for spring.

In this study, a station for SOC measurements was set up by the Laboratório de Luz Ultravioleta (LLUV, www.dfa.pucminas.br/ PUV/index.html) at the campus of the Pontifícia Universidade Católica de Minas Gerais (PUC Minas). It is called the LLUV station. The campus is settled on the top of a hill (911 $\mathrm{m}$ asl) in a crowded neighborhood. Small buildings are found among green areas that compose $43 \%$ of the local surface, and over 20,000 people can be found there on weekdays. The highest contribution of anthropogenic gases to SOC comes likely from the hundreds of thousands of vehicles crossing daily 3 large roads in the vicinity (less than $2 \mathrm{~km}$ away) of the campus.

\section{Instruments}

All instruments at the LLUV station were set up within a $250 \mathrm{~m}^{2}$ grassy area surrounded by small buildings at least $100 \mathrm{~m}$ from parking spaces.

\section{The Surface Ozone Monitor Model 202}

The Surface Ozone Monitor Model 202 (M202, 2B Technologies Inc., Bolder, USA) is a portable, lightweight monitor for ozone concentration measurements. It is based on the absorption by ozone molecules of the radiation at $253.7 \mathrm{~nm}$ from a low-pressure mercury lamp. Air samples are pumped into M202 through a Teflon membrane filter that retains the particle matter. A solenoid valve alternately switches air to a chamber or to an ozone scrubber. The difference in light absorption between these two samples gives the ozone concentration according to the Beer-Lambert Law. Pressure and temperature inside the chamber are monitored to give ozone measurements in ppbv units that are averaged over a time interval. M202 must be calibrated annually and have its op- erational parameters followed weekly using measurements of null ozone concentrations of air pumped through an external ozone scrubber. The presence of aromatic volatile compounds in the air can lead to SOC overestimation since these compounds are among the few contents of air absorbing at $253.7 \mathrm{~nm}$. On the other hand, special attention must be given to both the Teflon membrane filter and the ozone scrubber because the contamination with humidity can lead to the underestimation of SOC. Typically, M202 yields SOC measurements with precision and accuracy of 4 ppbv and $6 \%$ respectively.

\section{The Total Sky Imager}

The Total Sky Imager 440A (TSI, Yankee Environmental Systems, Inc., Turners Falls, USA) measures the cloud cover. It can be described as a digital camera facing down a rotating spherical mirror where the reflected sky is photographed at regular intervals. A black strip attached to the mirror avoids direct reflection of sunbeams into the camera. Each snapshot results in a colored JPEG image of 24-bits and resolution of $352 \times 288$ pixels. A program provided by the manufacturer and set up in a personal computer controls the imager and processes the captured images to determine the cloud cover. Uncertainties in the cloud cover measurements are $>10 \%$.

\section{Accessory equipment and data}

Local values of both temperature and atmospheric pressure around 16:00 hr universal time (UT) - or the noontime at 13:00 hr standard local time - were drawn from a Microtops II instrument (MII, Solar Light Co., Inc., Glenside, USA) (Morys et al., 2001) used in another project under LLUV (Silva \& Tomaz, 2012). $\mathrm{MII}$ is an instrument for the determination of the total ozone column (TOC) using the direct component of the solar radiation in the ultraviolet range. On the other hand, data referring to the meteorological parameters of wind direction and speed, number of rainy days, precipitation, humidity, and maximum temperature were obtained from the Instituto Nacional de Meteorologia (INMET, www.inmet.gov.br) that operates the meteorological station \#83587 in BH about $5 \mathrm{~km}$ away from the LLUV station. 


\section{Methodology}

Samples of outdoor air were collected at 1 minute resolution $2 \mathrm{~m}$ above the ground by the ozone monitor M202 through a $1 / 2 \mathrm{~m}$ length $\times 6.35 \mathrm{~mm}$ 0.d. Teflon tube, 24 hours a day from December 2009 to November 2010. A 5- $\mu$ m pore size Teflon membrane filter in the MIl's filter holder was replaced weekly to avoid contamination of the measurements by humidity. A procedure for the quality control and quality assurance of data was applied weekly to check both measurements and instrument. Data rejection was around $10 \%$ based on the occurrence of negative values of SOC. Then measurements were reduced to one-hour averages (1-h SOC) \pm 1 standard deviation $(1 \sigma)$.

The TSI was set up in the roof of a building close to the M202 set. The cloud cover within a $100^{\circ}$ field-of-view aperture was measured at 1 minute resolution and reduced to one-hour averages called the Local Cloud Cover (LCC) (Silva \& Souza-Echer, 2013). LCC and 1-h SOC were timely paired afterwards. The atmospheric condition during SOC measurements was obtained through the use of the TSI images.

Instruments were checked daily by a technician who also collected both the local temperature and atmospheric pressure from MII around 16:00 UT. Daily maxima of SOC occur about this time. To convert SOC from mixing ratio (ppbv) to mass concentration $\left(\mu \mathrm{g} / \mathrm{m}^{3}\right)$, measurements must be applied to the following expression,

$$
\left[\mu \mathrm{g} / \mathrm{m}^{3}\right]=\frac{0.577 p}{273.15+T}[p p b v],
$$

where $T$ is the local value of air temperature $\left({ }^{\circ} \mathrm{C}\right)$ and $p$ the atmospheric pressure (hPa). Although $[\mathrm{ppbv}]$ and $\left[\mu \mathrm{g} / \mathrm{m}^{3}\right]$ represent actually different physical units, herein we will adopt the former to indicate SOC since it is the unit used by M202.

\section{RESULTS AND DISCUSSION}

Apparently the main anthropogenic source of atmospheric pollutants in $\mathrm{BH}$ is the traffic of vehicles. Since the city has a relatively small territorial area, it is reasonable to suppose a homogeneous emission of both particles matter and gases to the atmosphere from the car and their exhausts. The accumulated precipitation in the site for the period of investigation was $1971.4 \mathrm{~mm}$ with the predominance of easterly and northeasterly winds (winds blowing from the east and the northeast respectively). Table 2 shows the seasonal averages for the solar elevation (The angular distance between the Sun and the horizon), temperature, and atmospheric pressure around 16:00 UT, and the wind direction and speed. Note that, the averages of solar elevation and temperature are related and increase in the order: winter, fall, spring, and summer. Re- garding SOC, the 1-h SOC values were obtained based on 54 SOC measurements per hour on average.

A detailed comparison of the SOC data obtained in this study with data from other authors (Massambani \& Andrade, 1994; Sánchez-Ccoyllo et al., 2006; FEAM, 2009; Teixeira et al., 2009; Alonso et al., 2010; Borrego et al., 2010; Corrêa et al., 2010) also working in Brazilian localities can be found in the work by Silva \& Tomaz (2013).

\section{SOC data from the LLUV station}

Daily maxima of 1-h SOC for the whole period of investigation are depicted in Figure 1. They range from 8.7 to $96.1 \mathrm{ppbv}$ and average $38.1 \pm 13.7 \mathrm{ppbv}$. The largest values are for summer and early spring when SOC exceeded the 90 ppbv limit. Lowest values spread along the 12-months with the exception of the winter-early spring period when a steady augmentation was observed. This effect was probably caused by the prevalence of the dry weather. The solar elevation in summer favors not only the incidence of solar radiation, but also the higher temperatures. Both are positive for SOC production. However, the precipitation in this season washes pollutants out of the troposphere and reduces SOC. On the other hand, the lower solar elevation in winter is counteracted by the rain shortage that extends till early spring. This can explain the steady augmentation of SOC in July-September. The bottom frame in Figure 1 shows the time for the occurrence of the daily maxima of 1-h SOC. It averages within the 15:00-16:00 UT period. An examination of the TSI images revealed cloudy skies with $\mathrm{LCC} \geq 77 \%$ for the 12 days in which the maxima of SOC OCcurred before 13:00 UT, 8 of them were rainy with 1-h SOC below the 12-month average of $38.1 \pm 13.7 \mathrm{ppbv}$. Both the reduction in the incidence of solar radiation by clouds and the removal of pollutants from the atmosphere by rain reduces SOC.

In general, the maxima of SOC occur around noon when the incidence of solar radiation is high and the concentration of ozone depleting substances is low. On the other hand, the minima of SOC occur at sunrise and sunset when the incidence of solar radiation is low and the concentration of ozone depleting substances like NO is high (Massambani \& Andrade, 1994; Sánchez-Ccoyllo et al., 2006). However, effects on SOC yielded by the transport of pollutants (including ozone) through winds from other places must be considered for a more detailed analysis, since it can explain some particular behaviors of SOC.

In the 12-months of the investigation, there were 3 events of 1-h SOC over 90 ppbv: one on February 3 (3FEB) and another two on September 15 (15SEP). Figure 2 depicts the SOC distribution for these days. Day 3FEB was a sunny and cloudless day 
Table 2 - Seasonal averages $\pm 1 \sigma$ for solar elevation, temperature, and atmospheric pressure around 16:00 UT (noontime), and wind direction and speed in $\mathrm{BH} . \mathrm{E}=$ Easterly, NE $=$ Northeasterly.

\begin{tabular}{|c|c|c|c|c|c|}
\hline \multirow{2}{*}{ Season } & \multirow{2}{*}{ Solar elevation $\left({ }^{\circ}\right)$} & \multirow{2}{*}{$\mathrm{T}\left({ }^{\circ} \mathrm{C}\right)$} & \multirow{2}{*}{$p(\mathrm{hPa})$} & \multicolumn{2}{|c|}{ Wind } \\
\cline { 5 - 6 } & & & & Direction & Speed $(\mathrm{m} / \mathrm{s})$ \\
\hline Summer & $86.1 \pm 2.9$ & $25.6 \pm 1.4$ & $911.3 \pm 2.4$ & $\mathrm{E}$ & $1.76 \pm 0.13$ \\
Fall & $61.0 \pm 8.9$ & $22.8 \pm 1.9$ & $912.2 \pm 2.2$ & $\mathrm{E}$ & $1.52 \pm 0.09$ \\
Winter & $50.9 \pm 4.6$ & $19.4 \pm 1.8$ & $911.7 \pm 2.3$ & $\mathrm{NE}$ & $1.65 \pm 0.05$ \\
Spring & $78.4 \pm 8.9$ & $24.4 \pm 2.2$ & $915.8 \pm 2.0$ & $\mathrm{NE}$ & $1.75 \pm 0.22$ \\
\hline
\end{tabular}
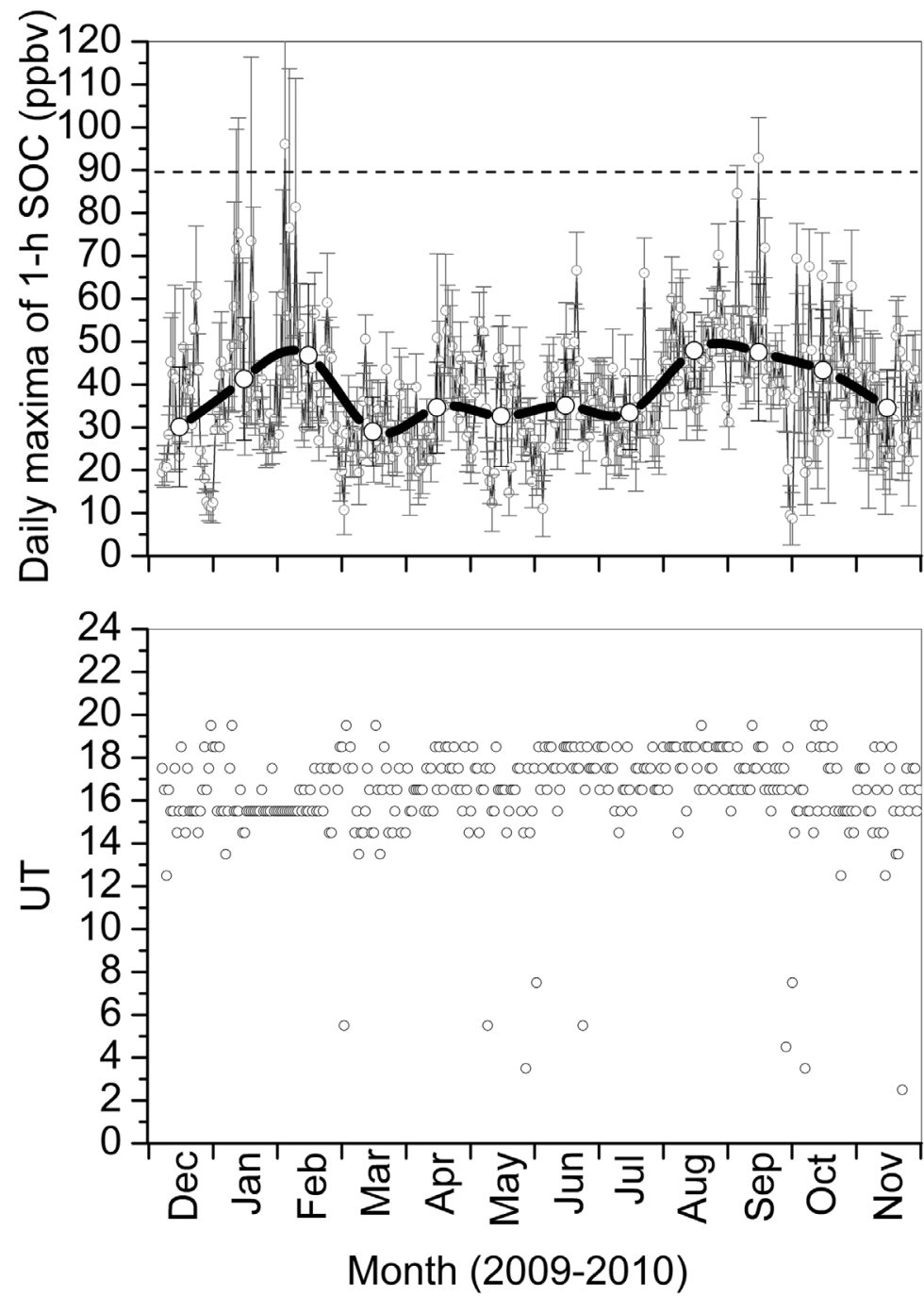

Figure 1 - (top) Daily maxima of 1-h surface ozone concentration (1-h SOC) $\pm 1 \sigma$ in BH. The black, thick line with open circles represents the monthly averages of the daily maxima of 1-h SOC. The dashed line marks the 90 ppbv limit. (bottom) Time of occurrence for the daily maxima of 1-h SOC. UT stands for Universal Time.

that turned into partially cloudy in the afternoon with LCC $\leq 35 \%$. Clouds were predominantly cumulus of medium to high vertical development whose optical thicknesses were probably high. The amounts of SOC evolved to the maximum $96.1 \mathrm{ppbv}\left(169 \mu \mathrm{g} / \mathrm{m}^{3}\right.$ using $T=27^{\circ} \mathrm{C}$ and $p=913 \mathrm{hPa}$ ) then decreased steeply.
This behavior can be caused by both a significant reduction in the incidence of solar radiation and variations in the meteorological parameters of humidity, temperature and winds.

Day 15SEP was a sunny and practically cloudless day for the largest part of the diurnal period. Turbidity and cloudiness 


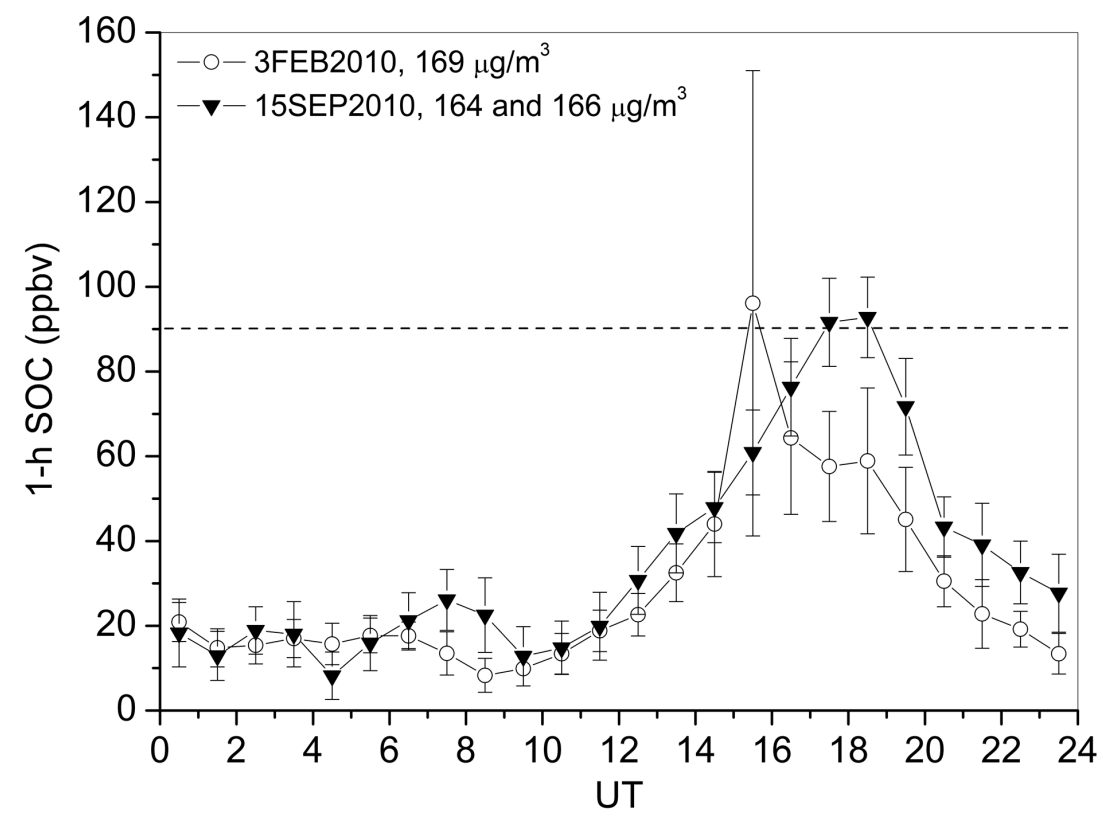

Figure 2 -1-h SOC in BH on February 3 and September 15 of 2010. These days had the occurrence of the highest maxima of 1-h SOC in the period of study.

appeared late in the afternoon. There were two 1-h SOC values >90 ppbv (91.6 and 92.8 ppbv) around 17:00-19:00 UT. They can be converted to 164 and $166 \mu \mathrm{g} / \mathrm{m}^{3}$, respectively, using $T=22^{\circ} \mathrm{C}$ and $p=914 \mathrm{hPa}$. Note that, the cloud cover difference between 3 FEB and 15SEP seems to be a fundamental aspect to understand the SOC distribution for these days, although the likely influence from other meteorological parameters must be considered. Thus the CONAMA limit for SOC was exceeded I0cally more than once in 12-months.

As the 1-h SOC distribution is affected by daily-specific factors, monthly averages seem to be more appropriate to investigate the general behavior of SOC. Figure 3 depicts the monthly averages of 1-h SOC for BH in the period of study. March had the lowest monthly average values (maximum of $24.5 \pm 8.8 \mathrm{ppbv}$ ), while August had the highest ones (maximum of $46.7 \pm 9.3 \mathrm{ppbv}$ ). Although the latter is practically twice as large as the former, both have similar level of variability for the monthly averages of $1-\mathrm{h}$ SOC in the diurnal period. Moreover, months with the highest occurrence of rainy days (and, probably, precipitation too) had the lowest monthly averages of 1-h SOC within each season. This is true for summer and spring and approximately true for fall and winter. In July and August, it is likely that the shortage of rain led to the augmentation of the concentration of atmospheric pollutants, resulting in the largest SOC values of August. On the other hand, from midnight to around 10:00 UT (the midnight-10 UT period), the boundary layer is calmer and cooler. It means the boundary layer contracts and a second-order maximum SOC is observed approximately in the middle of the midnight-10 UT period. In the dawn, the expansion of the boundary layer caused by the heating with the sunrise and the increasing in the NO concentrations by the traffic emission led to a minimum SOC around 8:00-10:00 UT. In general, the midnight-10 UT period showed SOC values of $\sim 10$ ppbv except for the August-October period when values double that mark. This probably results from the dry weather associated with the augmentation of pollutants in the atmosphere. A contribution from the transport of air masses can be considered.

The transformation of 1-h SOC to seasonal averages is depicted in Figure 4. This is another attempt to identify more widely general characteristics of SOC. Spring showed the highest values, while fall did the lowest ones. For these seasons, the average difference and average ratio between their seasonal averages of SOC were $7.9 \pm 1.2 \mathrm{ppbv}$ and $1.63 \pm 0.27$ respectively, which represent significant seasonal variations. All seasons showed similar lower amounts of SOC in the midnight-10 UT period but the spring. This can be caused by the influence of both the dry weather and the augmentation of pollutants in the atmosphere in the August-0ctober period. In addition, similar maxima of seasonal averages of 1-h SOC around local noontime were found for winter, spring, and summer. In summer, values were sharply reduced after the maximum at 15:00-16:00 UT. This clearly reflects the January and February data behavior shown in Figure 3, which 

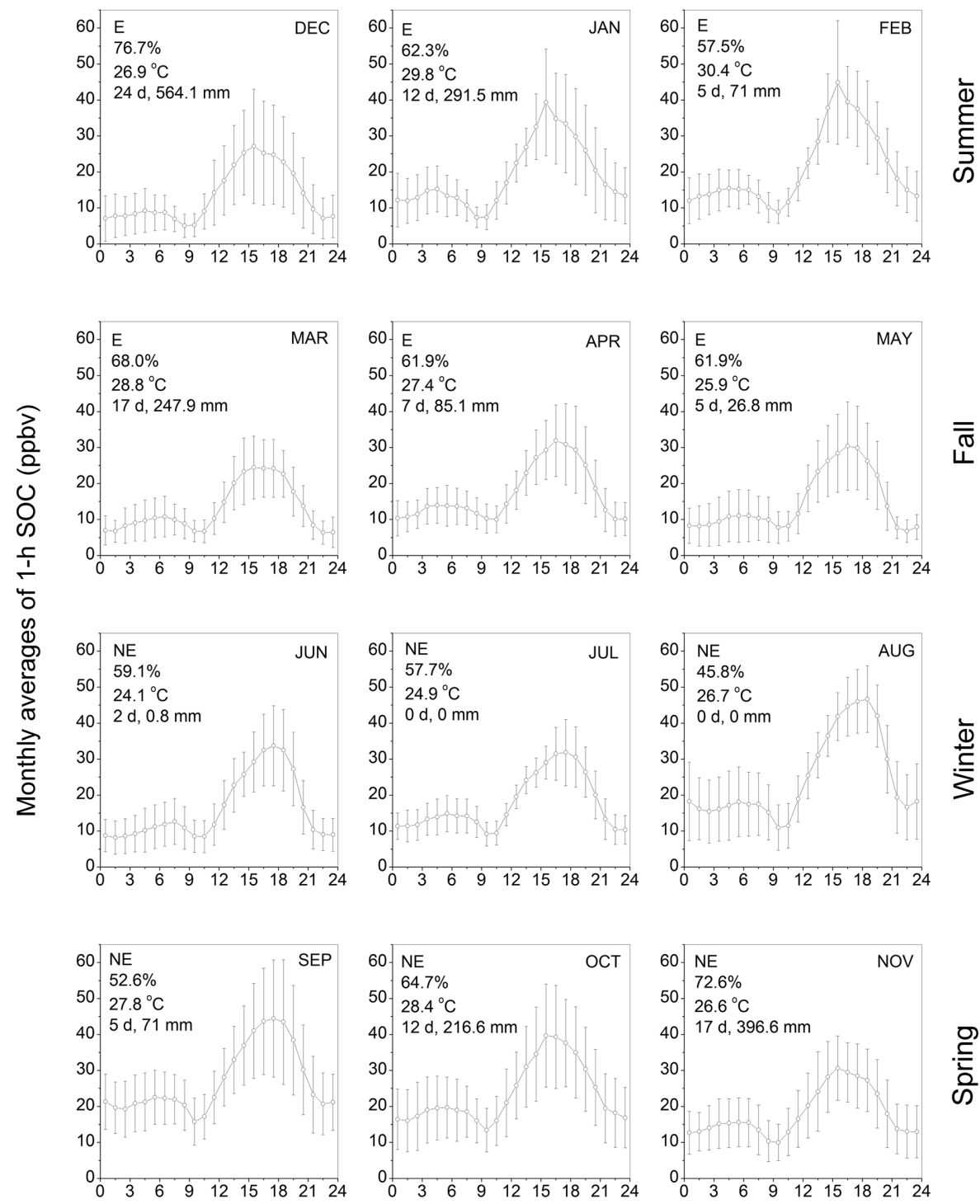

UT

Figure 3 - Monthly averages of 1-h SOC in 2009-2010 in BH. Inside-frame figures in the up-left corner are the monthly averages of wind direction, humidity, and maximum temperature, as well as the number of rainy days and precipitation.

is caused by many daily distributions of 1 -h SOC similar to the distribution on 3FEB. Such distributions result from the association between a reduction in the incidence of sunlight by the impressive formation of cloud cover and the likely variations in the meteorological condition in terms of humidity, temperature and winds. Clouds (specially the convective ones) develop through an intense lifting of warm and humid air parcels in the tropical troposphere, especially in the noon-afternoon period of summer. The bottom frame of Figure 4 depicts the seasonal averages of LCC for BH, where an LCC value over $85 \%$ at noon in summer timely corresponds to the sharp fall in the seasonal averages of 1-h SOC.

Nevertheless, a multitude of other atmospheric aspects in addition to the cloud cover must be taken into consideration to understand the SOC behavior. Although the seasonal average maxima of 1-h SOC for spring and winter are similar, they occurred under quite different amounts of LCC. Regarding the seasonal numbers of rainy days, they do not seem to be closely linked with the seasonal averages of 1-h SOC, differing from the analysis for the monthly averages of 1-h SOC (Fig. 3). In fact, summer and winter 
had 41 and 2 rainy days, respectively, with similar seasonal average maxima of 1-h SOC, while fall and spring had 29 and 34 rainy days, respectively, but with the most extreme values (maximum and minimum) of seasonal averages of 1-h SOC. Seasonal averages of solar elevation, temperature, and atmospheric pressure at 16:00 UT, and wind direction and speed in Table 2 summarize some important variables that somehow affect SOC. The atmospheric pressure and wind direction do not seem to be a preponderant aspect to be considered in this case, since they show low variability. Regarding the wind direction, note that the heavy traffic roads surrounding the LLUV station can lead to a scenario where winds carry similar amounts of pollutants whatever direction is considered.
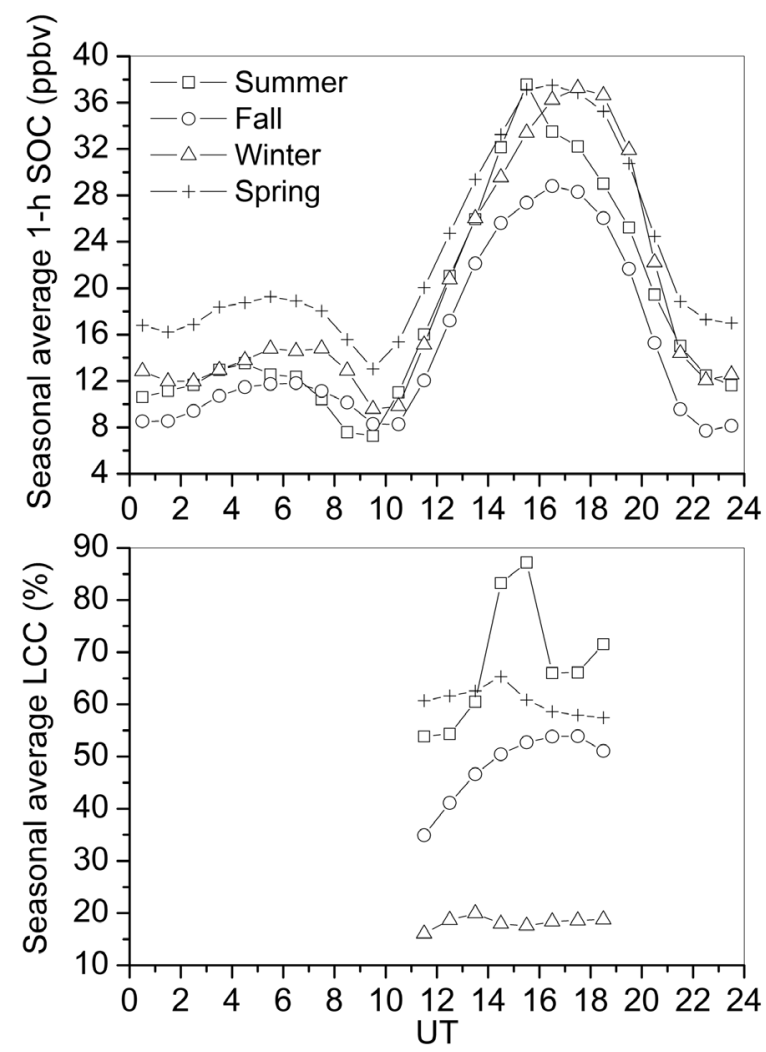

Figure 4 - Seasonal averages for both (top) 1-h SOC and (bottom) local cloud cover values in $\mathrm{BH}$.

\section{The quantitative dependence of SOC on some of the meteorological parameters}

If individually each of the daily meteorological parameters of humidity, wind speed, precipitation, and maximum temperature cannot explain the SOC behavior - especially if data like the cloud cover is considered - collectively they form a complex problem to be analyzed. A detailed investigation into such a complex problem, especially that referring to the dependence on LCC, is presently beyond the goals of this study. However, probing into the linear dependence of the monthly average values of 1-h SOC on the monthly average values of humidity, wind speed, precipitation, and maximum temperature showed that only for humidity a fair coefficient of determination $r^{2}=0.65$ (from a negative correlation coefficient of $r=-0.81$ ) and a percentage scattering SD\% $=19.7 \%$ of points around the straight line are obtained as it is shown by Figure 5. This result suggests the destructive action of the water vapor (the hydroxyl radical) on ozone. The obtained correlation coefficient has a $95 \%$ confidence interval $(\mathrm{Cl})$ against the null hypotheses $\left(\mathrm{H}_{0}: r=0\right.$, through the Fisher's statistical transformation). The linear fittings regarding the three other meteorological parameters yielded results of very poor quality, although the correlation coefficient for the wind speed has also shown a $95 \% \mathrm{Cl}$. Figure 6 shows both the corresponding $r^{2}$ and SD\% for the linear fittings of SOC with all the meteorological parameters.

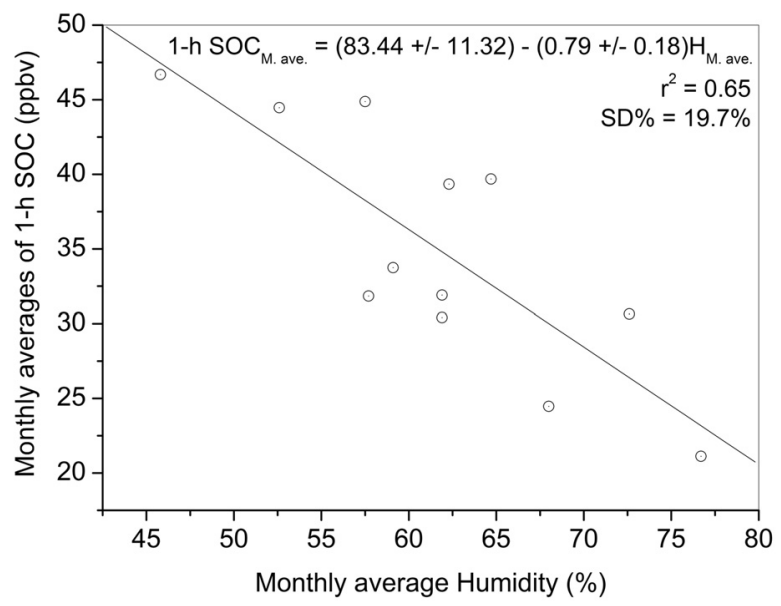

Figure $\mathbf{5}$ - Linear fitting between monthly average values of 1-h SOC (1-h $\mathrm{SOC}_{\mathbf{M}}$. ave. $)$ and humidity $\left(\mathrm{H}_{\mathbf{M}}\right.$. ave. $)$ for the period of investigation. Uncertainties are $1 \sigma$.

\section{CONCLUSION}

The 12-months of data of 1-h SOC in BH had daily maxima from 8.7 to $96.1 \mathrm{ppbv}$ around 15:00-16:00 UT and average of 38.1 \pm 13.7 ppbv $(1 \sigma)$. Dry period months (August-September) and February showed the highest daily maxima of 1-h SOC. The limit of $160 \mu \mathrm{g} / \mathrm{m}^{3}(\approx 90 \mathrm{ppbv}$ ) was reached in the sunny days of $3 \mathrm{FEB}$ $\left(169 \mu \mathrm{g} / \mathrm{m}^{3}\right)$ and 15 SEP $\left(164 \mu \mathrm{g} / \mathrm{m}^{3}\right.$ and $\left.166 \mu \mathrm{g} / \mathrm{m}^{3}\right)$. The daily development of 1-h SOC follows the habitual modulation with lows in the rush hours of sunrise and sunset. In terms of monthly averages, the maxima of SOC occurred around local noon, while the minima did within the 8-10 UT period. Maxima of monthly averages of 1-h SOC varied from $24.5 \pm 8.8 \mathrm{ppbv}$ in March to $46.7 \pm 9.3 \mathrm{ppbv}$ in August. The number of days with precipita- 
tion is inversely related to the amounts of SOC within a season on a monthly basis. The seasonal averages of 1-h SOC had the highest values in spring and the lowest ones in fall, being the average difference and the average ratio between these two seasons $7.9 \pm$ 1.2 ppbv and $1.63 \pm 0.27$ respectively. However, both summer and winter had maxima of 1-h SOC similar to spring. The main differences seem to have been produced by the climatology. In spring, the midnight-10 UT period showed the highest values of 1-h SOC, which seem to be caused by the dry weather, leading to the augmentation of pollutants in the atmosphere in the AugustOctober period. In summer, the formation of heavier cloud cover after $\sim$ 15:00 UT probably triggered the change in the local meteorological conditions that led to a steep decrease in the values of 1-h SOC. The use of ground-based data of cloud cover - the LCC parameter - significantly improved the analysis of SOC. The adoption of the LCC data gave support to a better understanding of the SOC behavior in cases like those observed in the summer afternoons.

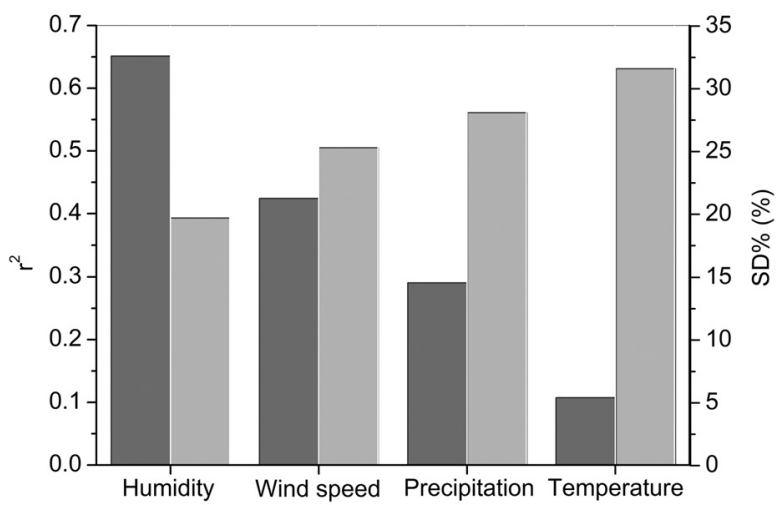

Figure 6 - (on the left) The coefficients of determination $r^{2}$ in dark-grey bars and (on the right) the percentage scattering SD\% in light-grey bars for the linear fittings between monthly average values of SOC vs. the meteorological parameters of humidity, wind speed, precipitation, and maximum temperature in $\mathrm{BH}$.

The meteorological parameter of humidity was the only one keeping a fair linear link with 1-h SOC among all the meteorological parameters in this investigation: $r^{2}=0.65(r=-0.81$ with $95 \% \mathrm{Cl}$ ) and a relatively large SD $\%=19.7 \%$ for monthly average values. Although the wind speed has also shown an $r$ with 95\% $\mathrm{Cl}$, it and the correlation coefficients for the other meteorological parameters were very poor showing increasing values of SD\%.

\section{ACKNOWLEDGEMENTS}

This work was financially supported by Fundação de Amparo à Pesquisa do Estado de Minas Gerais (FAPEMIG, CRA APQ 08485.02/07 and the fellowship to Luciano M. Tomaz) and Conselho Nacional de Pesquisa e Desenvolvimento (CNPq, 471441/2007-4 and other grants). Logistic support was provided by PUC Minas. Special thanks to the Provost of Research and Graduate Studies at PUC Minas, Prof. João F. de Abreu, for his crucial administrative support.

\section{REFERENCES}

ALONSO MF, LONGO KM, FREITAS SR, FONSECA RM, MARÉCAL V, PIRRE M \& KLENNER LG. 2010. An urban emissions inventory for South America and its application in numerical modeling of atmospheric composition at local and regional scales. Atmospheric Environment, 44: 5072-5083.

ATKINSON R. 2000. Atmospheric chemistry of VOCs and NOx. Atmospheric Environment, 34: 2063-2101.

BEIG G, GHUDE SD, POLADE SD \& TYAGI B. 2008. Threshold exceedances and cumulative ozone exposure indices at tropical suburban site. Geophysical Research Letters, 35: L02802, doi: 10.1029/2007GL031434.

BELL ML, McDERMOTT A, ZEGER SL, SAMET JM \& DOMINICI F. 2004. Ozone and short-term mortality in 95 US urban communities, 1987-2000. Journal of the American Medical Association, 292: 23722378.

BORREGO C, MONTEIRO A, FERREIRA J, MORAES MR, CARVALHO A, RIBEIRO I, MIRANDA AI \& MOREIRA DM. 2010. Modelling the photochemical pollution over the metropolitan area of Porto Alegre, Brazil. Atmospheric Environment, 44: 370-380.

BURLEY JD \& RAY JD. 2007. Surface ozone in Yosemite National Park. Atmospheric Environment, 41: 6048-6062.

CAMALIER L, COX, W \& DOLWICK P. 2007. The effects of meteorology on ozone in urban areas and their use in assessing ozone trends. Atmospheric Environment, 41: 7127-7137.

CIVEROLO K, HOGREFE C, LYNN B, ROSENTHAL J, KU J-Y, SOLECKI W, COX J, SMALL C, ROSENZWEIG C, GOLDBERG R, KNOWLTON K \& KINNEY P. 2007. Estimating the effects of increased urbanization on surface meteorology and ozone concentration in the New York City metropolitan region. Atmospheric Environment, 41: 1803-1818.

CORRÊA SM, ARBILLA G, MARTINS EM, QUITÉRIO SL, GUIMARÃES CS \& GATTI LV. 2010. Five years of formaldehyde and acetaldehyde monitoring in the Rio de Janeiro downtown area - Brazil. Atmospheric Environment, 44: 2302-2308.

DUNCAN BN, WEST JJ, YOSHIDA Y, FIORE AM \& ZIEMKE JR. 2008. The influence of European pollution on ozone in the Near East and northern Africa. Atmospheric Chemistry and Physics, 8: 2267-2283.

FEAM. Fundação Estadual do Meio Ambiente. 2009. Monitoramento da qualidade do ar na região metropolitana de Belo Horizonte em 2008. Belo Horizonte: FEAM. 47 pp. 
FLYNN J, LEFER B, RAPPENGLÜCK B, LEUCHNER M, PERNA R, DIBB J, ZIEMBA L, ANDERSON C, STUTZ J, BRUNE W, REN X, MAO J, LUKE W, OLSON J, CHEN G \& CRAWFORD J. 2010. Impact of clouds and aerosols on ozone production in Southeast Texas. Atmospheric Environment, 44: 4126-4133.

IBGE. Instituto Brasileiro de Geografia e Estatística. 2011. Available on: <http://www.ibge.gov.br/home/>. Access on: November 1, 2011.

IPCC. Intergovernmental Panel on Climate Change. 2007. Climate change 2007: The physical science basis. Fourth assessment report. Geneva: IPCC. 18 pp.

KIM JH \& NEWCHURCH MJ. 1998. Biomass-burning influence on tropospheric ozone over New Guinea and South America. Journal of Geophysical Research, 103: 1455-1461.

KOUVARAKIS G, TSIGARIDIS K, KANAKIDOU M \& MIHALOPOULOS N. 2000. Temporal variations of surface regional background ozone over Crete Island in the southeast Mediterranean. Journal of Geophysical Research, 105: 4399-4407.

LEGRAND M, PREUNKERT S, JOURDAIN B, GALLÉE H, GOUTAIL F, WELLER R \& SAVARINO J. 2009. Year-round record of surface ozone at coastal (Dumont d'Urville) and inland (Concordia) sites in East Antarctica. Journal of Geophysical Research, 114: D20306, doi: 10.1029/2008JD011667.

LIPPMANN M. 1991. Health-effects of tropospheric ozone. Environmental Science \& Technology, 25: 1954-1962.

McCONNELL R, BERHANE K, GILLILAND F, LONDON SJ, ISLAM T, GAUDERMAN WJ, AVOL E, MARGOLIS HG \& PETERS JM. 2002. Asthma in exercising children exposed to ozone: A cohort study. Lancet, 359: 386-391.

MASSAMBANI 0 \& ANDRADE F. 1994. Seasonal behavior of tropospheric ozone in the São Paulo (Brazil) metropolitan area. Atmospheric Environment, 28: 3165-3169.

MAZZEO NA, VENEGAS LE \& CHOREN H. 2005. Analysis of NO, $\mathrm{NO}_{2}$, $\mathrm{O}_{3}$ and $\mathrm{NO}$ x concentrations measured at a green area of Buenos Aires City during wintertime. Atmospheric Environment, 39: 3055-3068.

MELEUX F, SOLMON F \& GIORGI F. 2007. Increase in summer European ozone amounts due to climate change. Atmospheric Environment, 41: 7577-7587.

MORYS M, MIMS III FM, HAGERUP S, ANDERSON SE, BAKER A, KIA J \& WALKUP T. 2001. Design, calibration, and performance of MICROTOPS II handheld ozone monitor and Sun photometer. Journal of Geophysical Research, 106: 14573-14582.

OLTMANS SJ, LEFOHN AS, SCHEEL HE, HARRIS JM, LEVY $\| H$, GALBALLY IE, BRUNKE E-G, MEYER CP, LATHROP JA, JOHNSON BJ,
SHADWICK DS, CUEVAS E, SCHMIDLIN FJ, TARASICK DW, CLAUDE H, KERR JB \& UCHINO 0. 1998. Trends of ozone in the troposphere. Geophysical Research Letters, 25: 139-142.

PANDRANGI LS \& MORRISON GC. 2008. Ozone interactions with human hair: Ozone uptake rates and product formation. Atmospheric Environment, 42: 5079-5089.

SÁNCHEZ-CCOYLLO OR, YNOUE RY, MARTINS LD \& ANDRADE MF. 2006. Impacts of ozone precursor limitation and meteorological variables on ozone concentration in São Paulo, Brazil. Atmospheric Environment, 40: S552-S562.

SHAN W, YIN Y, ZHANG J \& DING Y. 2008. Observational study of surface ozone at an urban site in East China. Atmospheric Research, 89: 252-261.

SILVA AA. 2007. A quarter century of TOMS total column ozone measurements over Brazil. Journal of Atmospheric and Solar-Terrestrial Physics, 69: 1447-1458, doi: 10.1016/j.jastp.2007.05.006.

SILVA AA \& SOUZA-ECHER MP. 2013. Ground-based measurements of local cloud cover. Meteorology and Atmospheric Physics. 120: 201-212, doi: 10.1007/s00703-013-0245-9.

SILVA AA \& TOMAZ LM. 2012. Total ozone column measurements for an urban, tropical site in the Southern Hemisphere with a Microtops II. Journal of Atmospheric and Solar-Terrestrial Physics, 77: 161-166, doi: 10.1016/j.jastp.2011.12.014.

SILVA AA \& TOMAZ LM. 2013. Surface ozone concentrations and local cloud cover at an urban, tropical site in the Southern Hemisphere. Journal of Atmospheric and Solar-Terrestrial Physics, 105-106: 54-60, doi: 10.1016/j.jastp.2013.08.002.

TEIXEIRA EC, SANTANA ER, WIEGAND F \& FACHEL J. 2009. Measurement of surface ozone and its precursors in an urban area in South Brazil. Atmospheric Environment, 43: 2213-2220.

TILTON BE. 1989. Health effects of tropospheric ozone: Major effects and related scientific questions. Environmental Science \& Technology, 23: 257-263.

VELASCO E, MÁRQUEZ C, BUENO E, BERNABÉ RM, SÁNCHEZ A, FENTANES 0 , WÖHRNSCHIMMEL $H$, CÁRDENAS B, KAMILLA $A$, WAKAMATSU $S$ \& MOLINA LT. 2008. Vertical distribution of ozone and VOCs in the low boundary layer of Mexico City. Atmospheric Chemistry and Physics, 8: 3061-3079.

WHO. World Health Organization. 1987. Air quality guidelines for Europe. European Series No. 23, WHO Regional Publications, Copenhagen: WHO. 


\section{NOTE ABOUT THE AUTHOR}

Abel A. Silva is a physicist with master degree in Nuclear Sciences and doctorate in Space Geophysics. Currently, is a researcher and professor at the Instituto de Estudos Avançados (IEAv) and at the Pontifícia Universidade Católica de Minas Gerais (PUC Minas), where funded and coordinates the Laboratório de Luz UItravioleta (LLUV, www.dfa.pucminas.br/PUV/index.html). The main areas of interest are Space and Nuclear Geophysics within the themes: instrumentation for radiation measurements; ionizing and non-ionizing radiation; atmospheric radiation (radioisotopes, cosmic radiation, and solar ultraviolet radiation); atmospheric contents (ozone, clouds, and aerosols). 